DOI: 10.20472/IAC.2019.045.009

\author{
WANDA DUGIEL \\ Warsaw School of Economics, Poland
}

MAGDALENA MIKOŁAJEK-GOCEJNA

Warsaw School of Economics, Poland

\title{
TRADE POLICY OF THE UNITED STATES AND CHINA IN THE NEW ERA OF TRADE WARS: MACROECONOMIC AND BEHAVIORAL APPROACH
}

\begin{abstract}
:
The aim of the paper is to analyze the causes and effects of the growing protectionist tendencies in the US trade policy during the Donald Trump Presidency and the course of retaliatory actions of states, in particular China, in response to the increase of tariffs by the United States, for the development of international trade.

The study uses statistical data on the dynamics of international trade, trade exchange between trading partners, the level of tariffs, real GDP, the importance of industries covered by the trade war, in the economies of the United States, China and the European Union.

The analysis covers the motives of the United States in trade policy in 2018-2019, both in economic and behavioral terms, in particular the problem of market imperfections, the crisis of homoeconomicus in the face of growing dissatisfaction of societies in developed countries from pressure to further liberalization of the international trade, with financial constraints in politics social. At the heart of President Trump's protectionist actions were many of the same reasons that led to the waning US interest in further multilateral liberalization in the WTO.

The study uses statistical data, formulates a case study regarding the efficiency of the commercial dispute resolution system in the World Trade Organization (WTO). The study also uses a historical method. The comparative analysis concerns the contemporary trade conflict between the United States and China and the course and effects of the introduction of the Smoot-Hawley Act for trade in the United States in 1930.

The economic and social effects of the US trade wars with China and other trading partners, including the European Union, will become visible in the short run by 2020. Most of these effects will affect production levels, domestic prices, trade, GDP, social policy in The United States, which in future will be reviewing, trade policy tools in bilateral trade relation, with less involvement in WTO initiatives.

Controlled retaliation of US trading partners, China's conciliatory trade policy of unilateral concessions to China's access to the US market limits the likelihood of a global trade war, whose negative effects would affect most countries around the world.
\end{abstract}

\section{Keywords:}

trade wars, Section 232, protectionism, United States, homoeconomicus

JEL Classification: F02, F13 